Supporting Information

\title{
Linker Engineering Toward Full-Color Emission of UiO-68 Type Metal-Organic Frameworks
}

Shenjie Wu, ${ }^{\dagger}$ Daming Ren, ${ }^{\dagger}$ Kang Zhou,${ }^{\dagger}$ Hai-Lun Xia, ${ }^{\dagger}$ Xiao-Yuan Liu, ${ }^{*}, \dagger$ Xiaotai Wang, ${ }^{\dagger, \dagger}$ and Jing $\mathrm{Li}^{*},, \uparrow$

${ }^{\dagger}$ Hoffmann Institute of Advanced Materials, Shenzhen Polytechnic, 7098 Liuxian Blvd, Nanshan District, Shenzhen, 518055, People's Republic of China

\# Department of Chemistry, University of Colorado Denver, Campus Box 194, P. O. Box 173364, Denver, Colorado 80217-3364, United States

$\S$ Department of Chemistry and Chemical Biology, Rutgers University, 123 Bevier Road, Piscataway, New Jersey 08854, United States 


\section{Chemicals}

3,6-dibromobenzene-1,2-diamine

4,9-dibromonaphtho[2,3-c][1,2,5]thiadiazole (a1), 1,4-dibromonaphthalene-2,3-diamine, and 2',5'-dimethyl-[1,1':4',

1"-terphenyl]-4,4' '-dicarboxylic acid ( $d$ TPDC) were purchased from Jilin Chinese Academy of Science-Yanshen Technology Co., Ltd.. 4,7-dibromobenzo[c][1,2,5]thiadiazole (a3), methyl 4-bromo-3-methoxybenzoate, [1,1'-Bis(diphenylphosphino)ferrocene]dichloropalladium and bis(pinacolato)diboron were purchased from Shanghai Aladdin Biochemical Technology Co., Ltd. 4,7-dibromo-5,6-dimethylbenzo[c] $[1,2,5]$ thiadiazole and 4,7-dibromobenzo[c][1,2,5]selenadiazole $(\mathrm{a} 4)^{2}$ were synthesized according to reported works. All the other chemicals were obtained from the chemical supplies and used without further purification.

\section{Characterization}

Nuclear magnetic resonance (NMR) data was collected using 400 MHz JEOL JNM-ECZ400S. Powder X-ray diffraction (PXRD) patterns were measured using Bruker D8 Advance X-ray diffractometer with $\mathrm{Cu} \mathrm{K \alpha}$ radiation. Single crystal X-ray diffraction data were collected at $100 \mathrm{~K}$ on a Bruker D8 Venture diffractometer with graphite monochromated Ga K $\alpha$ radiation $(\lambda=1.34139 \AA)$. The photoluminescent spectra were recorded on FLS1000 spectrofluorometer (Edinburgh Instruments). The UV-vis spectra were recorded on Shimadzu UV-3600 spectrophotometer. The quantum yield was measured using C9920-03 absolute quantum yield measurement system (Hamamatsu Photonics) with a $150 \mathrm{~W}$ xenon monochromatic light source and 3.3 inch integrating sphere. 


\section{Density functional theory calculations}

Structures of compounds BAMB, MBTB, BTMB, BSMB, NTMB, NSMB, $\mathrm{Zr}_{6}$ cluster with $\mathrm{BTMB}$, and $\mathrm{Zr}_{6}$ cluster with NTMB were optimized and characterized by frequency calculations to be energy minima (zero imaginary frequencies) at the B $3 L Y P^{3} / 6-31 \mathrm{~g}(\mathrm{~d}, \mathrm{p})$ level of density functional theory (DFT). Fragments of UiO-68-BTMB and UiO-68-NTMB containing one $\mathrm{Zr}_{6}$ cluster and several organic linkers used in the calculations. Carboxylates in the organic linkers and four $\mu_{3}$-oxygen in the $\mathrm{Zr}_{6}$ cluster were terminated by hydrogen to ensure a neutral fragment. The HOMO-LUMO energies were then obtained from the output files. All calculations were performed with Gaussian 09. ${ }^{4}$ 
Synthesis of methyl 2-methoxy-4-(methoxycarbonyl)phenylboronic acid pinacol ester (1)

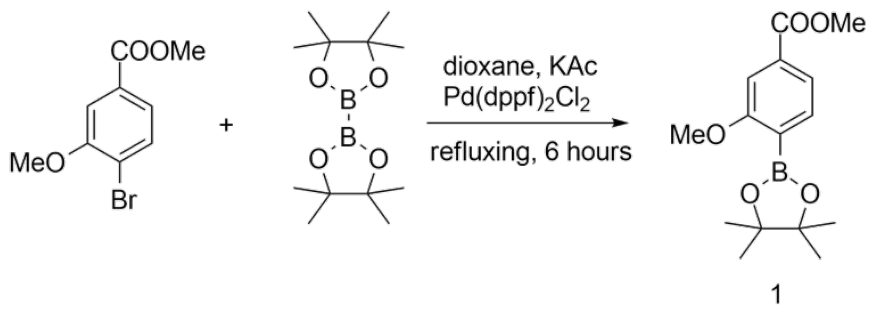

Methyl 4-bromo-3-methoxybenzoate (100.0 mmol, $24.5 \mathrm{~g})$, bis(pinacolato)diboron (120.0 mmol, $30.5 \mathrm{~g}), \quad$ potassium acetate $(285.0 \quad \mathrm{mmol}, \quad 28.0 \quad \mathrm{~g},)^{2}$ and [1,1'-Bis(diphenylphosphino)ferrocene]dichloropalladium (1.4 mmol, $1.0 \mathrm{~g}$,$) were added into$ one $500 \mathrm{~mL}$ round-bottle flask containing $300 \mathrm{~mL}$ dioxane. The mixture was stirred at $110^{\circ} \mathrm{C}$ for 6 hours. After cooling down to room temperature, the mixture was filtered and the organic solvent was removed under reduced pressure. The crude product was purified by a flash silica gel column chromatography to offer compound 1 as a white solid (yield: $95.6 \%$ ). ${ }^{1} \mathrm{H}$ NMR $\left(400 \mathrm{MHz}, \mathrm{CDCl}_{3}\right) \delta 7.68(1 \mathrm{H}), 7.57(1 \mathrm{H}), 7.48(1 \mathrm{H}), 3.90(\mathrm{~m}, 4 \mathrm{H}), 3.86(3 \mathrm{H}), 1.33(12 \mathrm{H})$.

\section{Synthesis of 4,9-dibromonaphtho[2,3-c][1,2,5] selenadiazole (a6)}

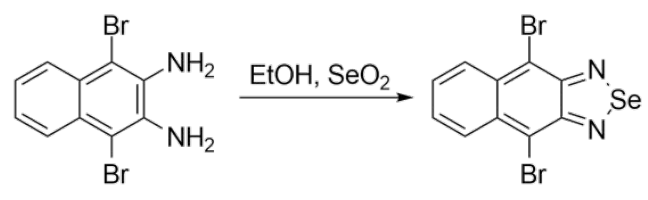

a6

1,4-dibromonaphthalene-2,3-diamine $(3.0 \mathrm{mmol}, 0.95 \mathrm{~g})$ was dissolved in $120 \mathrm{~mL}$ ethanol and then $\mathrm{SeO}_{2}(3.3 \mathrm{mmol}, 0.37 \mathrm{~g})$ in $10 \mathrm{~mL}$ hot water was added. The reaction solution was stirred at $85{ }^{\circ} \mathrm{C}$ for 8 hours. After cooling down to room temperature, the orange solid product a6 was filtered and washed using ethanol (yield: 99\%), which was directly used for next step without further purification. 


\section{Synthesis of c1-c6}<smiles>Nc1c(Br)ccc(Br)c1Br</smiles>

a1<smiles>COc1cc(C(C)=O)ccc1-c1ccc(-c2ccc(C(C)=O)cc2OC)c(N)c1N</smiles>

b7<smiles></smiles>

a2<smiles>CC(=O)c1ccc(B(O)O)cc1</smiles><smiles></smiles>

a3<smiles>COC(=O)c1ccc(B2OC(C)(C)C(C)(C)O2)c(OC)c1</smiles><smiles></smiles><smiles>Brc1ccc(Br)n2cnnc12</smiles>
$\mathrm{Br}$

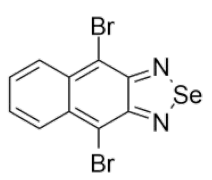

a6

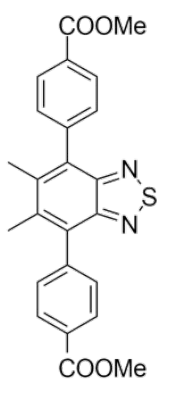

b2<smiles>C=Nc1c(-c2ccc(OC)cc2OC)ccc(-c2ccc(C(C)=O)cc2OC)c1N=N</smiles>

b3<smiles></smiles>

b4

THF, MeOH, water $\mathrm{NaOH}$ refluxing<smiles>Cc1c(C)c(-c2ccc(C(=O)O)cc2)c(N=N)c(C)c1-c1ccc(C(=O)O)cc1</smiles>

c2

MBTB<smiles>COc1cc(C(=O)O)ccc1-c1ccc(-c2ccc(C(=O)O)cc2OC)n2cnnc12</smiles>

c3

BTMB

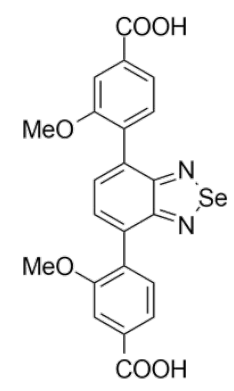

c4

BSMB general procedure 2<smiles>COc1ccc(C2=C3N=NN=C3C(c3ccc(OC)cc3OC)=C2c2ccc(C(C)=O)cc2OC)c(OC)c1</smiles>

b5<smiles>COC(=O)c1ccc(-c2c3ccccc3c(-c3ccc(C(C)=O)cc3OC)c3n[se]nc23)c(OC)c1</smiles>

b6<smiles>COc1cc(C(=O)O)ccc1-c1c2ccccc2c(-c2ccc(C(=O)O)cc2OC)c2nsnc12</smiles>

c5

NTMB<smiles>COc1cc(C(=O)O)ccc1C1=C2N=NN=C2C(c2ccc(C(=O)O)cc2OC)=C1c1ccccc1OC</smiles>

c6 NSMB

\section{General procedure 1}

Compound 1 (10 mmol), compound a $(4 \mathrm{mmol}), \mathrm{PdCl}_{2}(0.4 \mathrm{mmol}), \mathrm{PPh}_{3}(0.8 \mathrm{mmol})$ and $\mathrm{K}_{2} \mathrm{CO}_{3}(16 \mathrm{mmol})$ were added in a solution containing $120 \mathrm{~mL}$ dioxane and $30 \mathrm{~mL}$ water. The reaction solution was degassed four times. Then the mixture was heated to reflux at $105{ }^{\circ} \mathrm{C}$ for $24 \mathrm{~h}$ under nitrogen atmosphere. After cooling down to room temperature, the solvent was removed under reduced pressure and $100 \mathrm{~mL}$ DI water was added. The crude product was 
obtained after filtration and washed using DI water, which was directly used for next step without further purification.

\section{Dimethyl 4,4'-(5,6-dimethylbenzo[c][1,2,5]thiadiazole-4,7-diyl)bis(3-methoxybenzoate)} (b2) was synthesized according to general procedure 1 (yield: 89.6\%). ${ }^{1} \mathrm{H}$ NMR (400 MHz, $\left.\mathrm{CDCl}_{3}\right) \delta 8.38-8.16(4 \mathrm{H}), 7.68-7.44(4 \mathrm{H}), 3.98(6 \mathrm{H}), 2.35(4 \mathrm{H})$.

Dimethyl 4,4'-(benzo[c][1,2,5]thiadiazole-4,7-diyl)bis(3-methoxybenzoate) (b3) was synthesized according to general procedure 1 (yield: 92.5\%). ${ }^{1} \mathrm{H}$ NMR $\left(400 \mathrm{MHz}, \mathrm{CDCl}_{3}\right) \delta$ $7.80(2 \mathrm{H}), 7.75(4 \mathrm{H}), 7.66-7.62(2 \mathrm{H}), 3.96(6 \mathrm{H}), 3.87(6 \mathrm{H})$.

Dimethyl 4,4'-(benzo[c][1,2,5] selenadiazole-4,7-diyl)bis(3-methoxybenzoate) (b4) was synthesized according to general procedure 1 (yield: 92.3\%). ${ }^{1} \mathrm{H}$ NMR $\left(400 \mathrm{MHz}, \mathrm{CDCl}_{3}\right) \delta$ $7.79(2 \mathrm{H}), 7.74(4 \mathrm{H}), 7.58(4 \mathrm{H}), 3.96(6 \mathrm{H}), 3.85(6 \mathrm{H})$.

Dimethyl 4,4'-(naphtho[2,3-c][1,2,5]thiadiazole-4,9-diyl)bis(3-methoxybenzoate) (b5) was synthesized according to general procedure 1 (yield: $61.5 \%) .{ }^{1} \mathrm{H} \mathrm{NMR}\left(400 \mathrm{MHz}, \mathrm{CDCl}_{3}\right) \delta$ $7.89(2 \mathrm{H}), 7.85(2 \mathrm{H}), 7.68(2 \mathrm{H}), 7.57-7.46(\mathrm{~m}, 2 \mathrm{H}), 7.35-7.28(2 \mathrm{H}), 4.00(6 \mathrm{H}), 3.81-3.75$ $(6 \mathrm{H})$.

Dimethyl 4,4'-(naphtho[2,3-c][1,2,5] selenadiazole-4,9-diyl)bis(3-methoxybenzoate) (b6) was synthesized according to general procedure 1 (yield: $58.8 \%$ ). ${ }^{1} \mathrm{H}$ NMR (400 $\mathrm{MHz}, \mathrm{CDCl}_{3}$ ) $\delta$ 7.76-7.67 (4H), $7.52(1 \mathrm{H}), 7.48-7.43(1 \mathrm{H}), 7.40-7.32(2 \mathrm{H}), 7.27-7.19(2 \mathrm{H}), 3.91(6 \mathrm{H}), 3.72-$ $3.63(6 \mathrm{H})$.

Dimethyl 2',3'-diamino-2,2"'-dimethoxy-[1,1':4',1"-terphenyl]4,4"-dicarboxylate (b7) was synthesized according to general procedure 1 and purified by silica gel column chromatography (yield: 45.4\%). ${ }^{1} \mathrm{H}$ NMR (400 MHz, $\left.\mathrm{CDCl}_{3}\right) \delta 7.80(2 \mathrm{H}), 7.76(2 \mathrm{H}), 7.73-$ 
$7.67(2 \mathrm{H}), 7.64(2 \mathrm{H}), 3.98(6 \mathrm{H}), 3.91(6 \mathrm{H})$.

\section{General procedure 2}

$4.0 \mathrm{mmol}$ compound $\mathbf{b}$ was added to a solution containing $50 \mathrm{~mL} \mathrm{CH}_{3} \mathrm{OH}, 100 \mathrm{~mL}$ THF and $50 \mathrm{~mL}$ water with $5.5 \mathrm{~g} \mathrm{NaOH}$. The mixture was heated to reflux at $80{ }^{\circ} \mathrm{C}$ overnight. After cooling down to room temperature, the organic solvent was removed under reduced pressure and the resulted aqueous was filtered. Then the filtrate was neutralized using $2 \mathrm{M} \mathrm{HCl}$ to obtain the precipitate, which was filtered to offer the final product c.

4,4'-(5,6-dimethylbenzo[c] $][1,2,5]$ thiadiazole-4,7-diyl)bis(3-methoxybenzoic acid) (c2, MBTB) was synthesized according to general procedure 2 as a white solid (yield: 81.4). ${ }^{1} \mathrm{H}$ NMR (400 MHz, DMSO-d $) 13.14(2 \mathrm{H}), 8.07(4 \mathrm{H}), 7.58(4 \mathrm{H}), 2.29(6 \mathrm{H})$.

4,4'-(benzo[c] $[1,2,5]$ thiadiazole-4,7-diyl)bis(3-methoxybenzoic acid) (c3, BTMB) was synthesized according to general procedure 2 as a yellow solid (yield: 90.6\%). ${ }^{1} \mathrm{H}$ NMR (400 MHz, DMSO- $\left.d_{6}\right) \delta 13.10(2 \mathrm{H}), 7.75(2 \mathrm{H}), 7.68-7.63(4 \mathrm{H}), 7.62-7.57(2 \mathrm{H}), 3.77(6 \mathrm{H})$.

4,4'-(benzo[c] $[1,2,5]$ selenadiazole-4,7-diyl)bis(3-methoxybenzoic acid) (c4, BSMB) was synthesized according to general procedure 2 as a light orange solid (yield: $86.8 \%$ ). ${ }^{1} \mathrm{H}$ NMR $\left(400 \mathrm{MHz}, \mathrm{DMSO}-d_{6}\right) \delta 13.02(2 \mathrm{H}), 7.63(4 \mathrm{H}), 7.53(4 \mathrm{H}), 3.74(6 \mathrm{H})$.

4,4'-(naphtho[2,3-c][1,2,5]thiadiazole-4,9-diyl)bis(3-methoxybenzoic acid) (c5, NTMB) was synthesized according to general procedure 2 as an orange solid (yield: $89.4 \%$ ). ${ }^{1} \mathrm{H}$ NMR (400 MHz, DMSO- $\left.d_{6}\right) \delta 13.01(2 \mathrm{H}), 7.72(4 \mathrm{H}), 7.63-7.14(4 \mathrm{H}), 6.80(2 \mathrm{H}), 3.81-3.67(6 \mathrm{H})$.

4,4'-(naphtho[2,3-c][1,2,5] selenadiazole-4,9-diyl)bis(3-methoxybenzoic acid) (c6, NSMB) was synthesized according to general procedure 2 as a purple solid (yield: $83.6 \%$ ). ${ }^{1} \mathrm{H}$ NMR $\left(400 \mathrm{MHz}, \mathrm{DMSO}-d_{6}\right) \delta 13.10(2 \mathrm{H}), 7.76-7.65(4 \mathrm{H}), 7.49(1 \mathrm{H}), 7.43(1 \mathrm{H}), 7.36(2 \mathrm{H})$, 


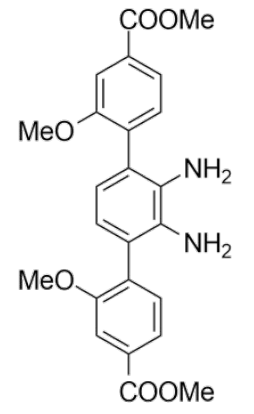

b7

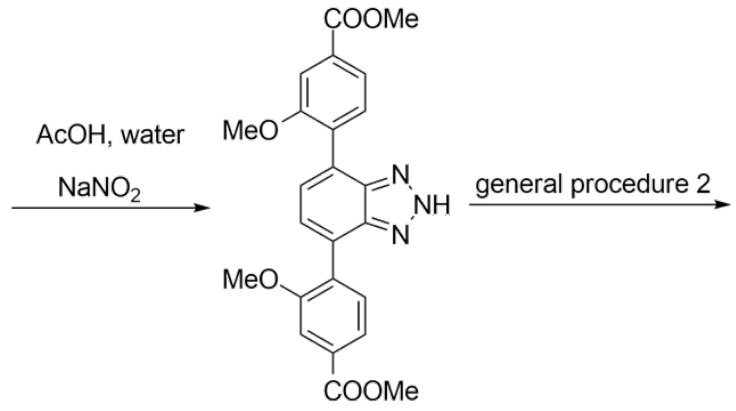

b1

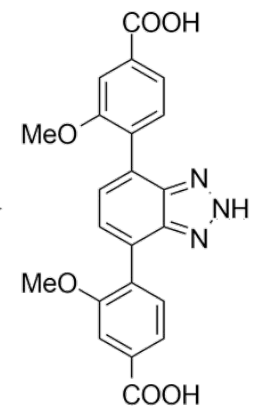

c1

Synthesis of dimethyl 4,4'-(2H-benzo[d][1,2,3]triazole-4,7-diyl)bis(3-methoxybenzoate) (b1)

Compound b7 (0.35 g, $0.8 \mathrm{mmol})$ and $\mathrm{NaNO}_{2}(75 \mathrm{mg}, 1.1 \mathrm{mmol})$ were added into a mixture solution of $10 \mathrm{~mL}$ water and $5 \mathrm{~mL}$ acetate acid. The reaction solution was stirred at room temperature for 2 hours and then $\mathrm{CH}_{2} \mathrm{Cl}_{2}(30 \mathrm{~mL})$ was added. The organic phase was separated, washed using water and dried using anhydrous $\mathrm{Na}_{2} \mathrm{SO}_{4}$. Compound b1 was obtained as a gray solid after removing the organic solvent under reduced pressure (yield: 98\%). ${ }^{1} \mathrm{H}$ NMR (400 MHz, $\left.\mathrm{CDCl}_{3}\right) \delta 7.80(2 \mathrm{H}), 7.76(2 \mathrm{H}), 7.73-7.67(2 \mathrm{H}), 7.64(2 \mathrm{H}), 3.98$ $(6 \mathrm{H}), 3.91(6 \mathrm{H})$.

4,4'-(2H-benzo[d][1,2,3]triazole-4,7-diyl)bis(3-methoxybenzoic acid) (c1, BAMB) was synthesized according to general procedure 2 as a gray solid (yield: $87.6 \%$ ). ${ }^{1} \mathrm{H}$ NMR (400 $\left.\mathrm{MHz}, \mathrm{DMSO}-d_{6}\right) \delta 12.75(2 \mathrm{~h}), 7.72-7.60(6 \mathrm{H}), 7.50(2 \mathrm{H}), 3.80(6 \mathrm{H})$.

\section{Synthesis of UiO-68-L (L: BAMB, MBTB, BTMB, BSMB, NTMB and NSMB)}

$\mathrm{ZrCl}_{4}(11.2 \mathrm{mg}, 0.048 \mathrm{mmol})$, organic linker $(0.07 \mathrm{mmol})$ and benzoic acid $(222.6 \mathrm{mg}, 1.82$ mmol) were added into a $5 \mathrm{~mL}$ vial containing $3 \mathrm{~mL}$ DMF. After sonicated for 5 minutes, the vial was put into a preheated oven at $120^{\circ} \mathrm{C}$ for 24 hours. After cooling down to room 
temperature, the octahedral single crystals were obtained, which was washed using DMF for several times until no fluorescent single was detected from the supernatant.

Synthesis of mixed linker UiO-68-L/dTPDC (L: MBTB, BTMB, BSMB, NTMB and NSMB)

UiO-68-L/dTPDC was synthesized using the same method as UiO-68-L, while different ratios of $\mathrm{L}$ and $d \mathrm{TPDC}$ were used for the synthesis as shown in Table S1. 
Table S1. The synthesis conditions for UiO-68-L/dTPDC.

\begin{tabular}{|c|c|c|c|c|c|c|}
\hline \multicolumn{7}{|c|}{$\mathrm{ZrCl}_{4} 11.2 \mathrm{mg}$, benzoic acid $222.6 \mathrm{mg}, \mathrm{DMF} 3 \mathrm{~mL}, 0.07 \mathrm{mmol}$ linkers } \\
\hline & $\begin{array}{l}\text { MW of MBTB } \\
\qquad(\mathrm{g} / \mathrm{mol})\end{array}$ & $\begin{array}{l}\text { mmol of } \\
\text { MBTB }\end{array}$ & $\begin{array}{l}\text { W of MBTB } \\
(\mathrm{mg})\end{array}$ & $\begin{array}{l}\text { MW of } d \text { TPDC } \\
\quad(\mathrm{g} / \mathrm{mol})\end{array}$ & $\begin{array}{l}\text { mmol of } \\
\text { TPDC }\end{array}$ & $\begin{array}{c}\mathrm{W} \text { of } d \mathrm{TPDC} \\
(\mathrm{mg})\end{array}$ \\
\hline $1: 1$ & 404 & 0.0350 & 14.14 & 346 & 0.0350 & 12.11 \\
\hline $1: 2$ & 404 & 0.0233 & 9.43 & 346 & 0.0467 & 16.15 \\
\hline $1: 5$ & 404 & 0.0117 & 4.71 & 346 & 0.0583 & 20.18 \\
\hline \multirow[t]{2}{*}{$1: 10$} & 404 & 0.0064 & 2.57 & 346 & 0.0636 & 22.02 \\
\hline & $\begin{array}{c}\text { MW of BTMB } \\
\quad /(\mathrm{g} / \mathrm{mol})\end{array}$ & $\begin{array}{c}\text { mmol of } \\
\text { BTMB }\end{array}$ & $\begin{array}{l}\text { W of BTMB } \\
\quad / \mathrm{mg}\end{array}$ & $\begin{array}{c}\text { MW of } d \text { TPDC } \\
\quad /(\mathrm{g} / \mathrm{mol})\end{array}$ & $\begin{array}{c}\text { mmol of } \\
\text { TPDC }\end{array}$ & $\begin{array}{c}\mathrm{W} \text { of } d \text { TPDC } \\
(\mathrm{mg})\end{array}$ \\
\hline $1: 1$ & 436 & 0.0350 & 15.26 & 346 & 0.0350 & 12.11 \\
\hline $1: 2$ & 436 & 0.0233 & 10.17 & 346 & 0.0467 & 16.15 \\
\hline $1: 5$ & 436 & 0.0117 & 5.09 & 346 & 0.0583 & 20.18 \\
\hline \multirow[t]{2}{*}{$1: 10$} & 436 & 0.0064 & 2.77 & 346 & 0.0636 & 22.02 \\
\hline & $\begin{array}{c}\text { MW of BSMB } \\
\quad /(\mathrm{g} / \mathrm{mol})\end{array}$ & $\begin{array}{c}\text { mmol of } \\
\text { BSMB }\end{array}$ & $\begin{array}{l}\text { W of BSMB } \\
\quad / \mathrm{mg}\end{array}$ & $\begin{array}{c}\text { MW of } d \text { TPDC } \\
\quad /(\mathrm{g} / \mathrm{mol})\end{array}$ & $\begin{array}{c}\text { mmol of } \\
\text { TPDC }\end{array}$ & $\begin{array}{c}\text { W of } d \text { TPDC } \\
(\mathrm{mg})\end{array}$ \\
\hline $1: 1$ & 484 & 0.0350 & 16.94 & 346 & 0.0350 & 12.11 \\
\hline $1: 2$ & 484 & 0.0233 & 11.29 & 346 & 0.0467 & 16.15 \\
\hline $1: 5$ & 484 & 0.0117 & 5.65 & 346 & 0.0583 & 20.18 \\
\hline \multirow[t]{2}{*}{$1: 10$} & 484 & 0.0064 & 3.08 & 346 & 0.0636 & 22.02 \\
\hline & $\begin{array}{c}\text { MW of NTMB } \\
\quad /(\mathrm{g} / \mathrm{mol})\end{array}$ & $\begin{array}{c}\text { mmol of } \\
\text { NTMB }\end{array}$ & $\begin{array}{c}\text { W of NTMB } \\
\quad / \mathrm{mg}\end{array}$ & $\begin{array}{c}\text { MW of } d \text { TPDC } \\
\quad /(\mathrm{g} / \mathrm{mol})\end{array}$ & $\begin{array}{c}\text { mmol of } \\
\text { TPDC }\end{array}$ & $\begin{array}{c}\text { W of } d \text { TPDC } \\
(\mathrm{mg})\end{array}$ \\
\hline $1: 1$ & 486 & 0.0350 & 17.01 & 346 & 0.0350 & 12.11 \\
\hline $1: 2$ & 486 & 0.0233 & 11.34 & 346 & 0.0467 & 16.15 \\
\hline $1: 5$ & 486 & 0.0117 & 5.67 & 346 & 0.0583 & 20.18 \\
\hline \multirow[t]{2}{*}{$1: 10$} & 486 & 0.0064 & 3.09 & 346 & 0.0636 & 22.02 \\
\hline & $\begin{array}{c}\text { MW of NSMB } \\
\quad /(\mathrm{g} / \mathrm{mol})\end{array}$ & $\begin{array}{c}\text { mmol of } \\
\text { NSMB }\end{array}$ & $\begin{array}{c}\text { W of NSMB } \\
\quad / \mathrm{mg}\end{array}$ & $\begin{array}{c}\text { MW of } d \text { TPDC } \\
\quad /(\mathrm{g} / \mathrm{mol})\end{array}$ & $\begin{array}{c}\text { mmol of } \\
\text { TPDC }\end{array}$ & $\begin{array}{c}\text { W of } d \text { TPDC } \\
(\mathrm{mg})\end{array}$ \\
\hline $1: 1$ & 534 & 0.0350 & 18.69 & 346 & 0.0350 & 12.11 \\
\hline $1: 2$ & 534 & 0.0233 & 12.46 & 346 & 0.0467 & 16.15 \\
\hline $1: 5$ & 534 & 0.0117 & 6.23 & 346 & 0.0583 & 20.18 \\
\hline $1: 10$ & 534 & 0.0064 & 3.40 & 346 & 0.0636 & 22.02 \\
\hline
\end{tabular}




\section{Single-crystal X-ray diffraction analyses}

Single crystals of UiO-68-BTMB and UiO-68-NTMB were mounted on MicroMesh (MiTeGen) with paraton oil. The data was collected on a 'Bruker D8 VENTURE Metaljet PHOTON II' diffactometer with Ga K $\alpha$ microfocus X-ray source. The crystals were kept at the $100 \mathrm{~K}$ during data collection. Using Olex $2^{5}$, the structures were solved with the ShelXT ${ }^{6}$ structure solution program using Intrinsic Phasing and refined with the ShelXL ${ }^{7}$ refinement package using Least Squares minimization. For both of compounds the ligand moiety was disordered and atoms were refined using geometry restraints (DFIX, SADI, FLAT, SAME). Restraints were also used to refine anisotropic displacement parameters of all non-hydrogen atoms (SIMU). The disordered non-coordinated solvents were removed using the PLATON SQUEEZE program. The refinement results are summarized in Table S2 and S3. Crystallographic data for the UiO-68-BTMB and UiO-68-NTMB crystal structures in CIF format have been deposited in the Cambridge Crystallographic Data Centre (CCDC) under deposition numbers CCDC-2082073 (UiO-68-BTMB) and 2082074 (UiO-68-NTMB). The data can be obtained free of charge via www.ccdc.cam.ac.uk/data_request/cif (or from the Cambridge Crystallographic Data Centre, 12 Union Road, Cambridge CB2 1EZ, U.K.). 


\section{Digestion Procedure of MOFs for ${ }^{1} \mathrm{H}$ NMR measurement}

$10 \mathrm{mg}$ as-synthesized mixed-linker UiO-68-BTMB/dTPDC were washed three times using DMF, then the collected solid samples in $5 \mathrm{~mL}$ vials were put into one $150{ }^{\circ} \mathrm{C}$ oven overnight. After cooling down to room temperature, $50 \mathrm{uL} 12 \mathrm{M} \mathrm{HCl}$ was added into the vials, which were put into one $100{ }^{\circ} \mathrm{C}$ oven to dry for several hours. Then $800 \mathrm{uL}$ DMSO- $d_{6}$ was added to dissolve the resulted organic linkers. After filtering, the solution of DMSO- $d_{6}$ containing linkers was used for the ${ }^{1} \mathrm{H}$ NMR measurement. 


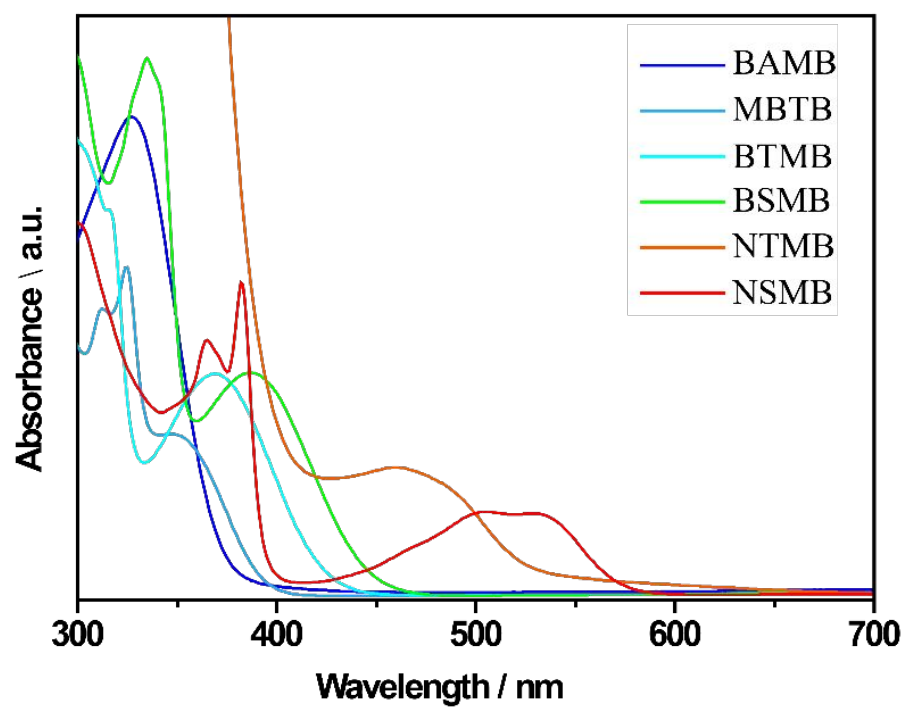

Figure S1. UV-vis absorption spectra of BAMB, MBTB, BTMB, BSMB, NTMB and NSMB in DMF. 

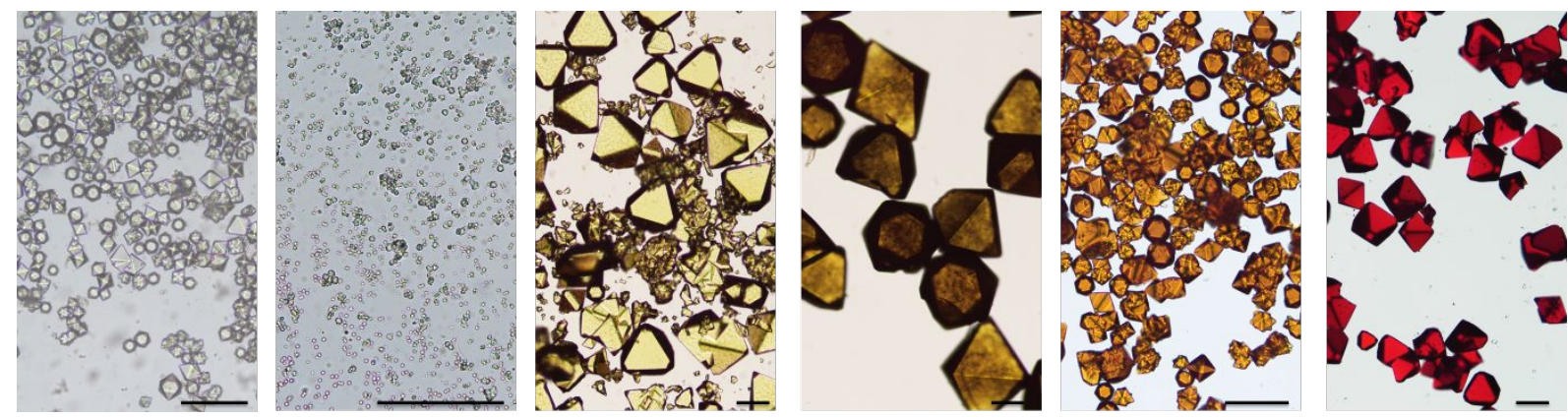

Figure S2. Optical images of UiO-68-BAMB, UiO-68-MBTB, UiO-68-BTMB, UiO-68-BSMB, UiO-68-NTMB and UiO-68-NSMB (scale bar: $100 \mathrm{~nm}$ ). 

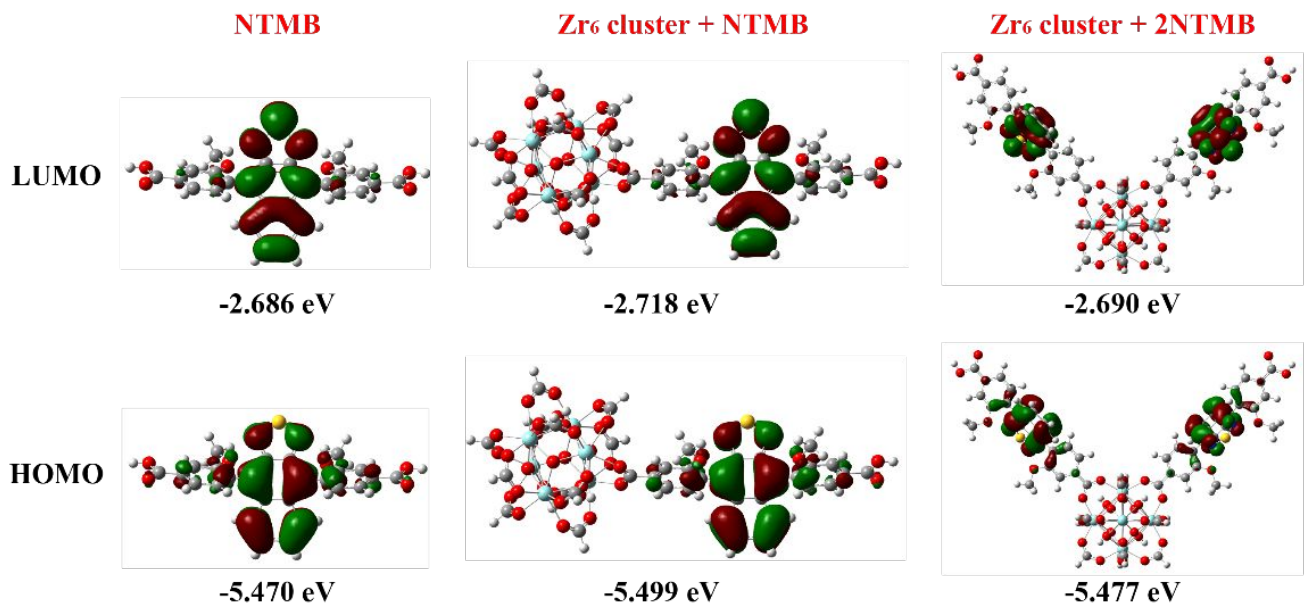

Zr6 cluster +4 NTMB
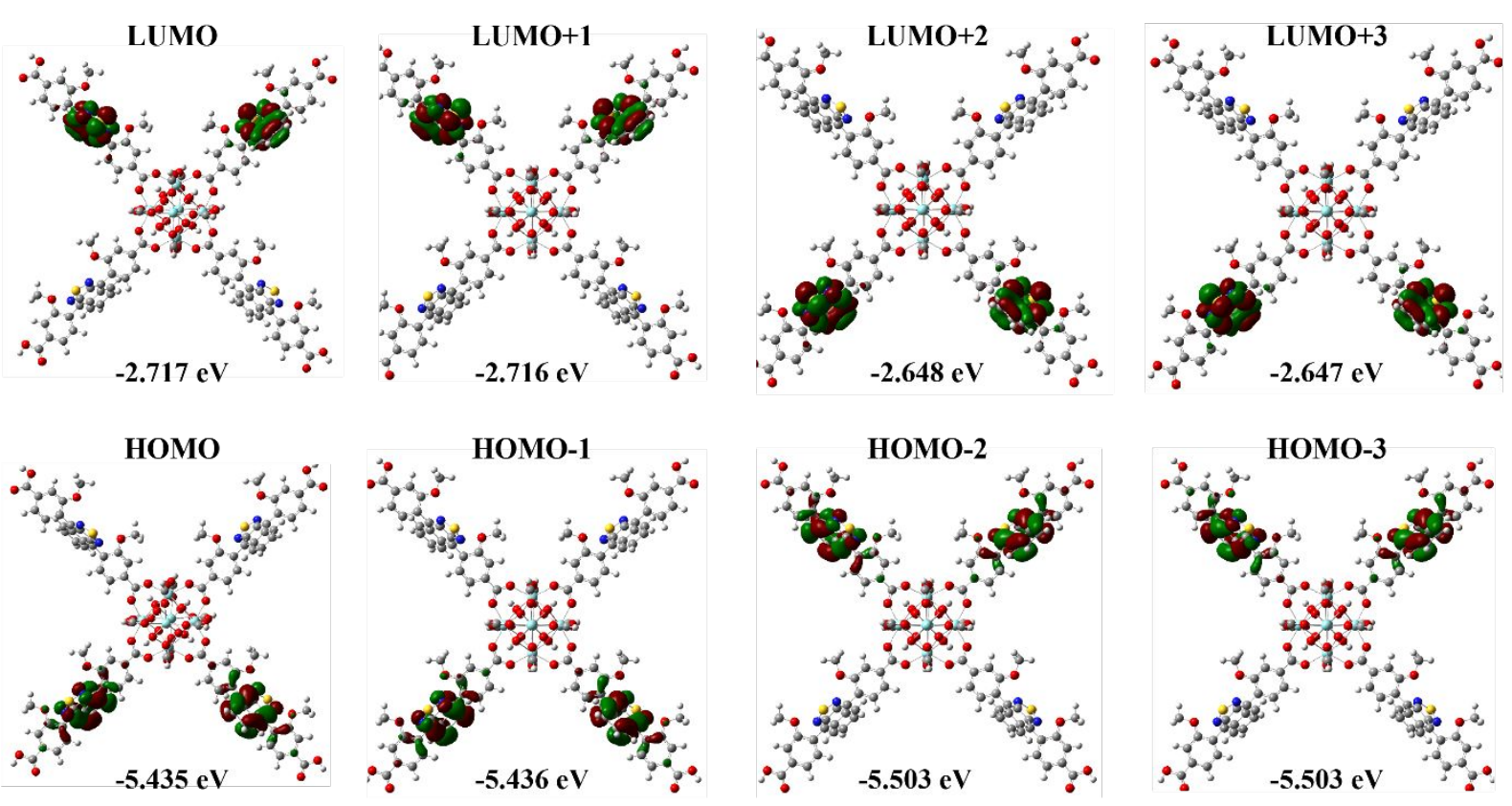

Figure S3. The orbital surfaces, HOMO and LUMO energies for NTMB, $\mathrm{Zr}_{6}$ cluster $+\mathrm{NTMB}, \mathrm{Zr}_{6}$ cluster $+2 \mathrm{NTMB}$ and $\mathrm{Zr}_{6}$ cluster $+4 \mathrm{NTMB}$. 
ВТМB

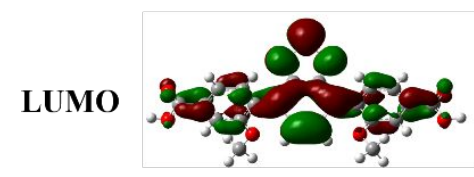

$-2.464 \mathrm{eV}$

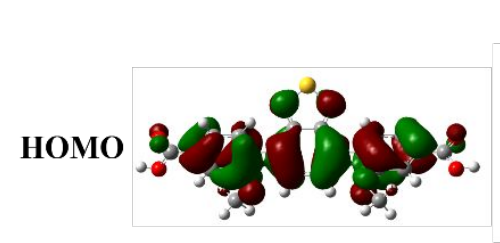

$-5.771 \mathrm{eV}$
Zr6 cluster + BTMB

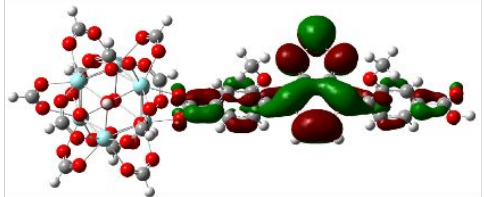

$-2.407 \mathrm{eV}$

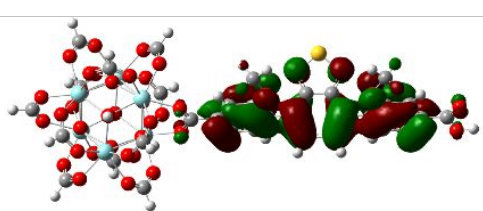

$-5.994 \mathrm{eV}$

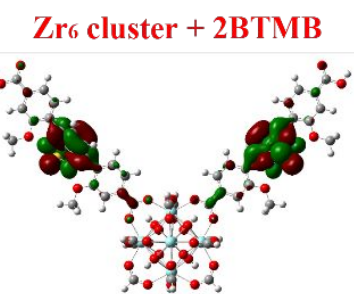

$-2.394 \mathrm{eV}$

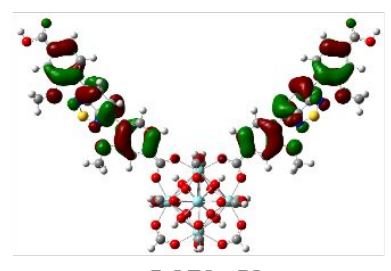

$-5.970 \mathrm{eV}$

Zr6 cluster + 4BTMB
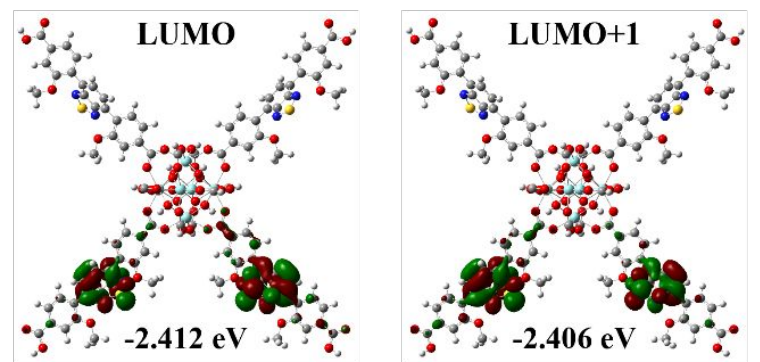

$\because-2.406$ eV $\because$

HOMO

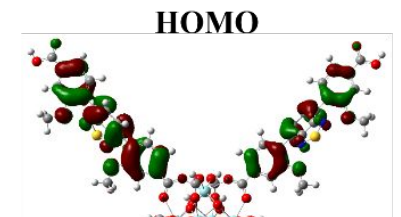

aso

0
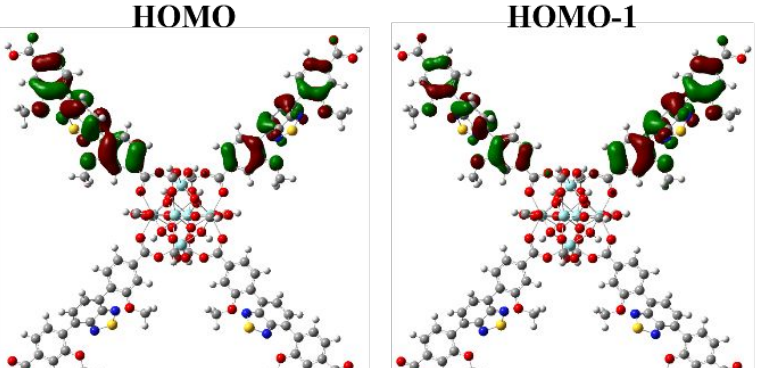

0.

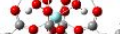
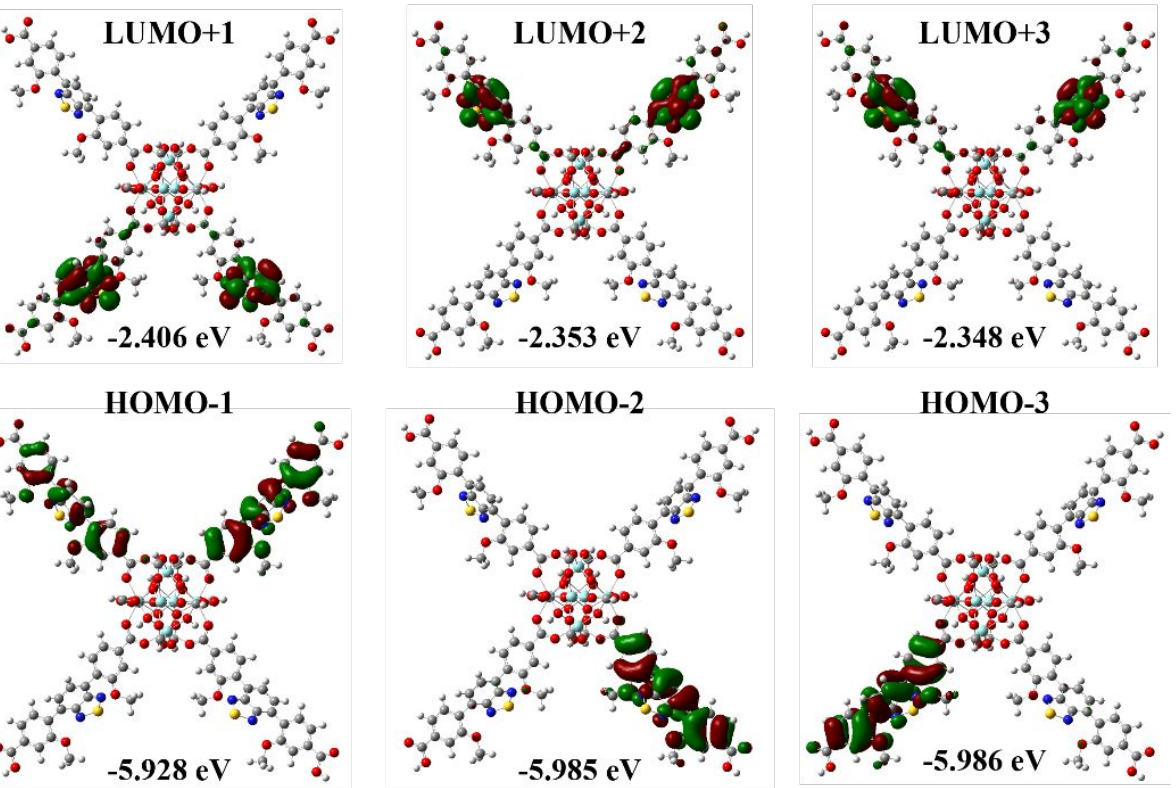

Figure S4. The orbital surfaces, HOMO and LUMO energies for BTMB, $\mathrm{Zr}_{6}$ cluster $+\mathrm{BTMB}, \mathrm{Zr}_{6}$ cluster $+2 \mathrm{BTMB}$ and $\mathrm{Zr}_{6}$ cluster $+4 \mathrm{BTMB}$. 


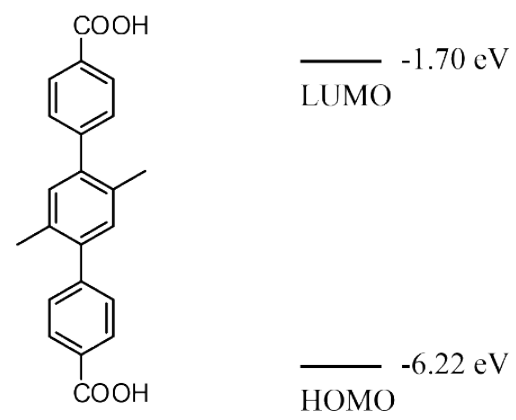

Figure S5. The molecular structure and calculated HOMO-LUMO energy level of 2',5'-dimethyl-[1,1':4', 1"-terphenyl]-4,4"-dicarboxylic acid (dTPDC). 

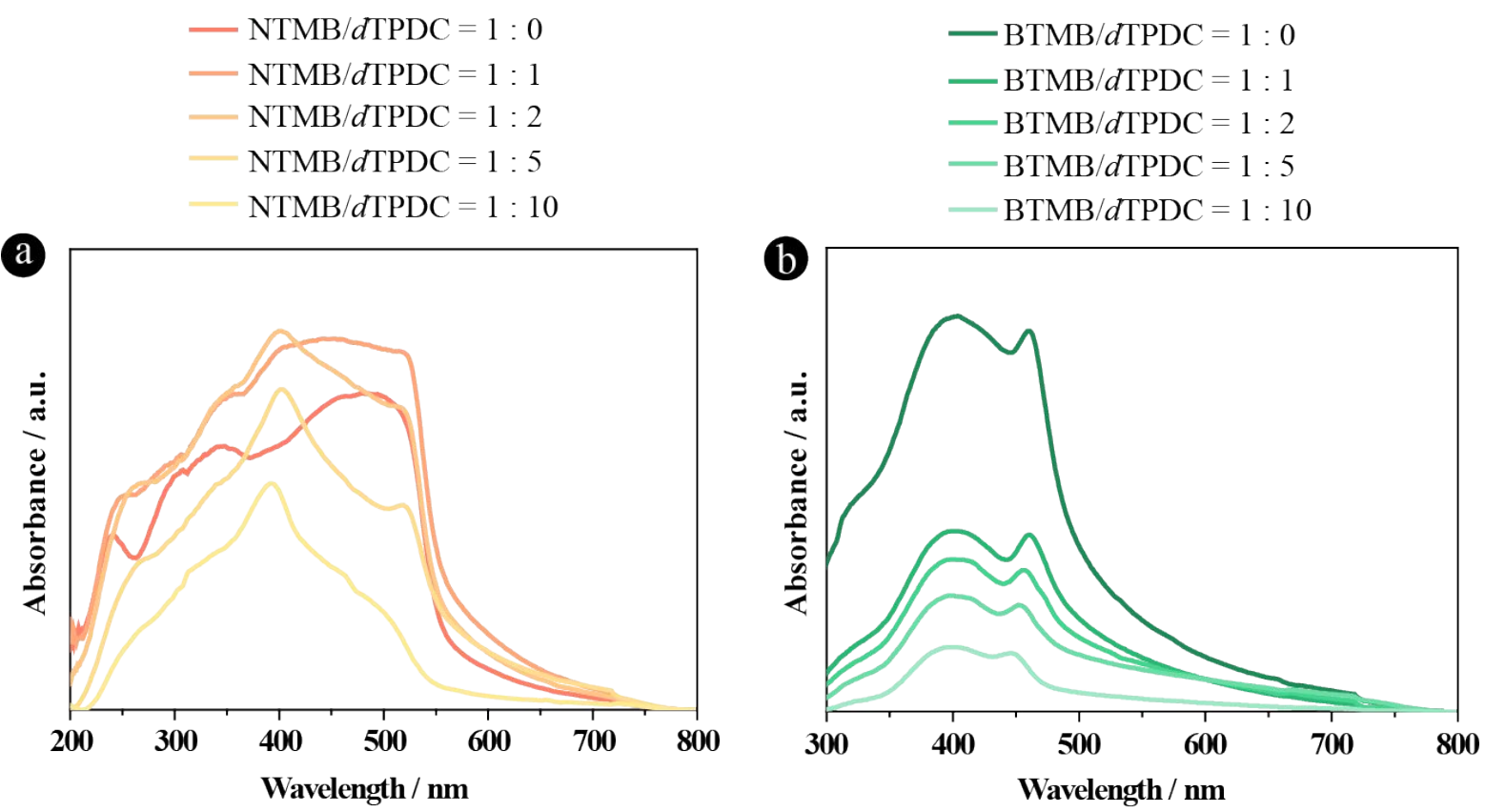

Figure S6. The UV-vis absorption spectra of UiO-68-NTMB (a) and UiO-68-BTMB (b) with different concentrations of $d$ TPDC. 

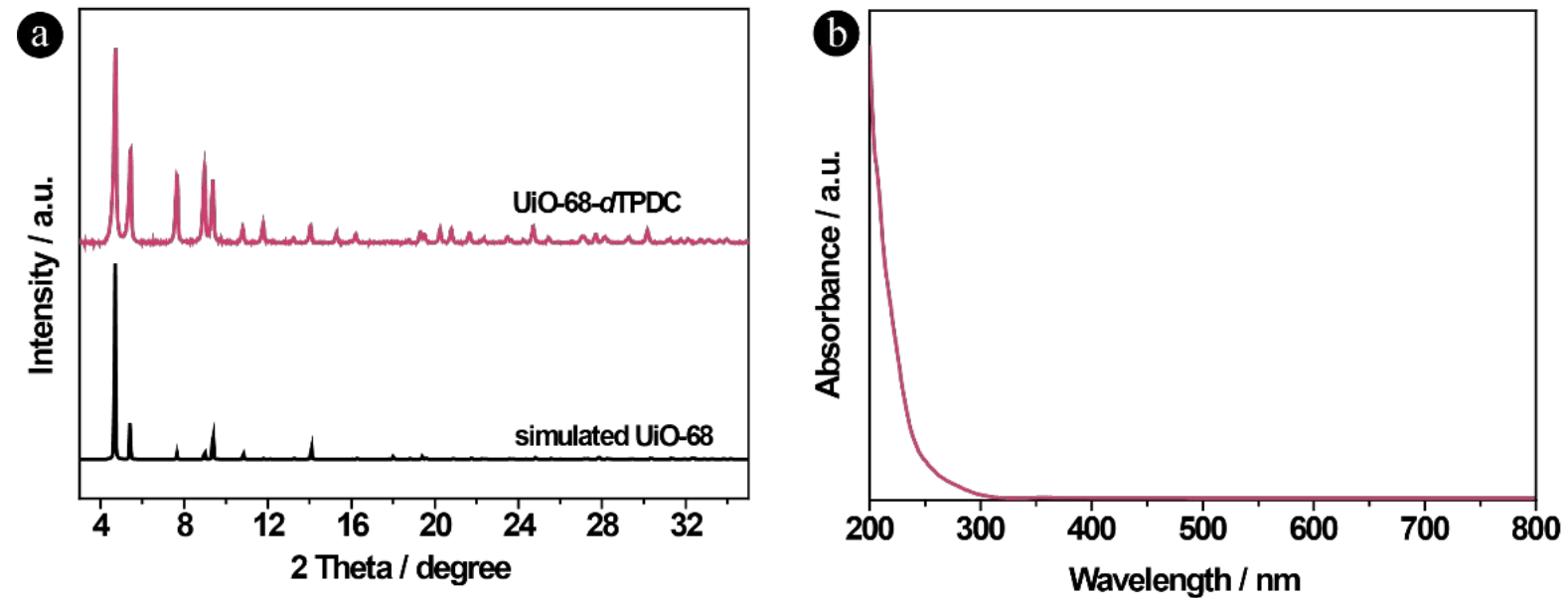

Figure S7. (a) The PXRD patterns of simulated UiO-68 and as-synthesized UiO-68- $d$ TPDC, and (b)

UV-vis absorption spectrum of UiO-68-dTPDC. 
Table S2. Estimated total radiative and non-radiative decay rates.

\begin{tabular}{|c|c|c|c|c|c|c|c|c|}
\hline BTMB/dTPDC & $\tau_{1}(\mathrm{~ns})$ & $\mathrm{A}_{1}(\%)$ & $\tau_{2}(\mathrm{~ns})$ & $\mathrm{A}_{2}(\%)$ & $\tau_{\mathrm{PL}}(\mathrm{ns})$ & PLQY (\%) & $\begin{array}{c}k_{\mathrm{r}} \\
\left(\mathrm{x} 10^{8}, \mathrm{~s}^{-1}\right)\end{array}$ & $\begin{array}{c}k_{\mathrm{nr}} \\
\left(\mathrm{x} 10^{8}, \mathrm{~s}^{-1}\right)\end{array}$ \\
\hline $1: 0$ & 3.50 & 12.02 & 7.96 & 87.98 & 7.42 & 36.0 & 0.49 & 0.86 \\
\hline $1: 1$ & 7.73 & 100 & - & - & 7.73 & 40.5 & 0.52 & 0.77 \\
\hline $1: 2$ & 7.95 & 100 & - & - & 7.95 & 44.3 & 0.56 & 0.70 \\
\hline $1: 5$ & 7.92 & 100 & - & - & 7.92 & 56.2 & 0.71 & 0.55 \\
\hline $1: 10$ & 8.13 & 100 & - & - & 8.13 & 47.8 & 0.59 & 0.64 \\
\hline $\mathrm{NTMB} / d \mathrm{TPDC}$ & $\tau_{1}(\mathrm{~ns})$ & $\mathrm{A}_{1}(\%)$ & $\tau_{2}(\mathrm{~ns})$ & $\mathrm{A}_{2}(\%)$ & $\tau_{\mathrm{PL}}(\mathrm{ns})$ & PLQY $(\%)$ & $k_{\mathrm{r}}$ & $k_{\mathrm{nr}}$ \\
\hline $1: 2$ & 3.38 & 46.35 & 9.95 & 53.65 & 6.90 & 1.70 & 0.02 & 1.42 \\
\hline $1: 5$ & 5.22 & 18.94 & 14.64 & 81.06 & 12.86 & 11.4 & 0.09 & 0.69 \\
\hline $1: 10$ & 6.94 & 13.92 & 17.48 & 86.08 & 16.01 & 18.8 & 0.12 & 0.51 \\
\hline
\end{tabular}

The total radiative and non-radiative decay rates for UiO-68-L/dTPDC were estimated based on the following equations:

$$
\begin{gathered}
\eta=k_{\mathrm{r}} /\left(k_{\mathrm{r}}+k_{\mathrm{nr}}\right) \\
\tau_{\mathrm{PL}}=1 /\left(k_{\mathrm{r}}+k_{\mathrm{nr}}\right)
\end{gathered}
$$

Where $\eta$ is the quantum yield, $k_{\mathrm{r}}$ is the total radiative rate and $k_{\mathrm{nr}}$ is the total nonradiative rate for a biexponential decay, $\tau_{\mathrm{PL}}=\mathrm{A}_{1} \tau_{1}+\mathrm{A}_{2} \tau_{2}\left(\mathrm{~A}_{1}, \mathrm{~A}_{2}\right.$ are the fractional amplitudes; $\tau_{1}, \tau_{2}$ are the corresponding lifetimes). 

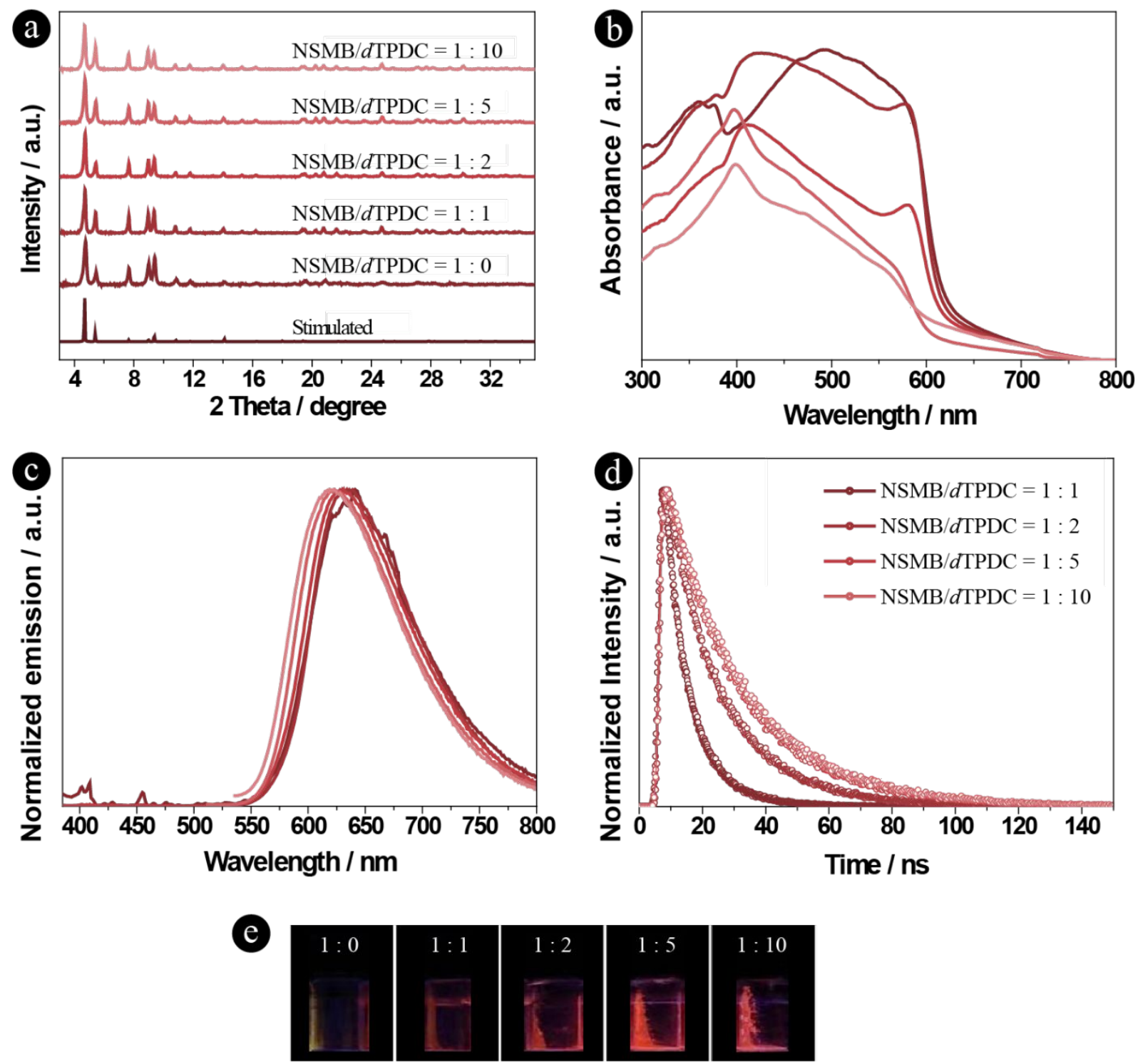

UiO-68-NSMB/dTPDC

Figure S8. (a) PXRD patterns, (b) solid-state UV-vis absorption spectra, (c) normalized solid-state emission spectra, (d) solid-state transient fluorescence decay profiles and (e) photographs under 365 nm excitation of the mixed linker UiO-68-NSMB with different concentrations of $d$ TPDC. 

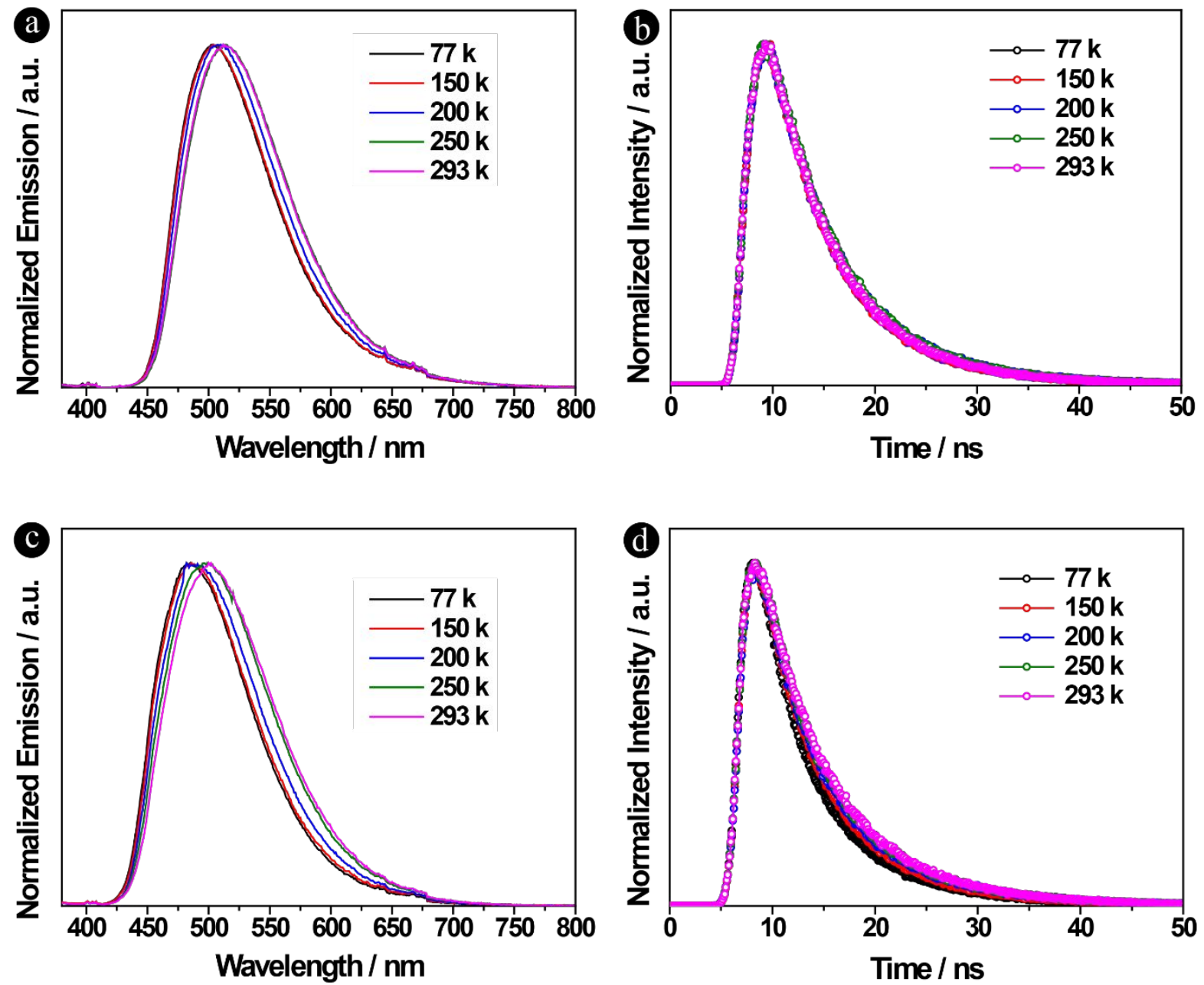

Figure S9. Normalized emission spectra of (a) UiO-68-BTMB and (c) UiO-68-BTMB/dTPDC $(\mathrm{BTMB} / d \mathrm{TPDC}=1: 5)$, and the corresponding transient fluorescence decay profiles (b) UiO-68-BTMB and (d) UiO-68-BTMB/ $d$ TPDC $(\mathrm{BTMB} / d \mathrm{TPDC}=1: 5)$ under different temperatures. 

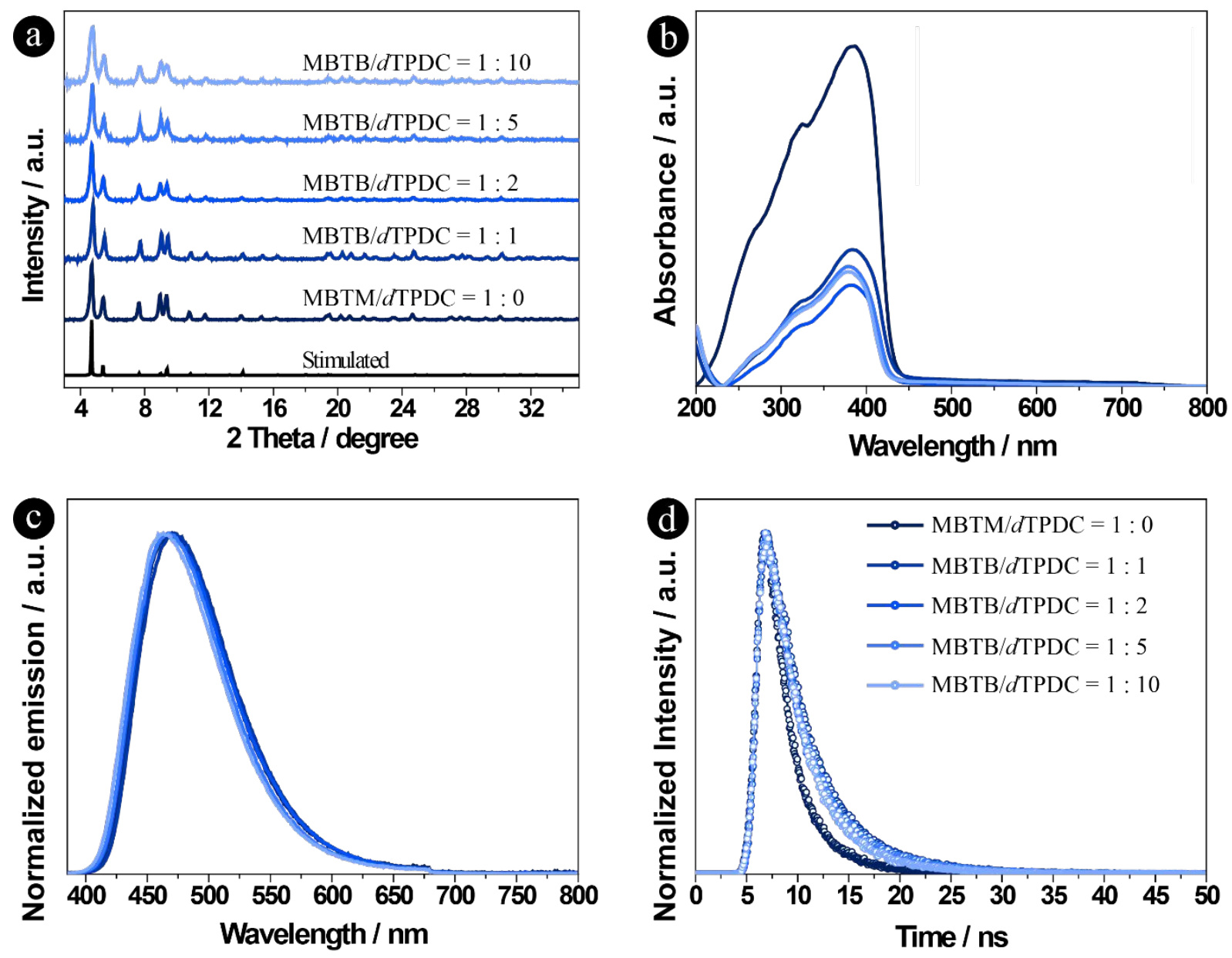

e

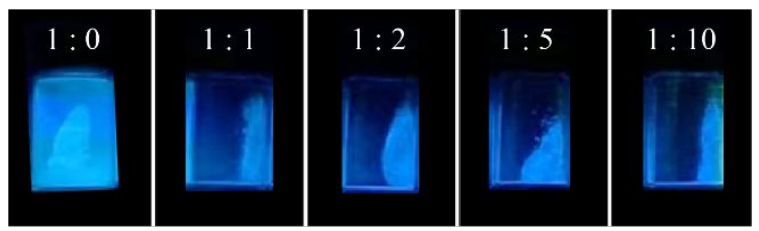

UiO-68-MBTB/ $d$ TPDC

Figure S10. (a) PXRD patterns, (b) solid-state UV-vis absorption spectra, (c) normalized solid-state emission, (d) solid-state transient fluorescence decay profiles and (e) photographs under $365 \mathrm{~nm}$ excitation of mixed linker UiO-68-MBTB with different concentrations of $d$ TPDC. 

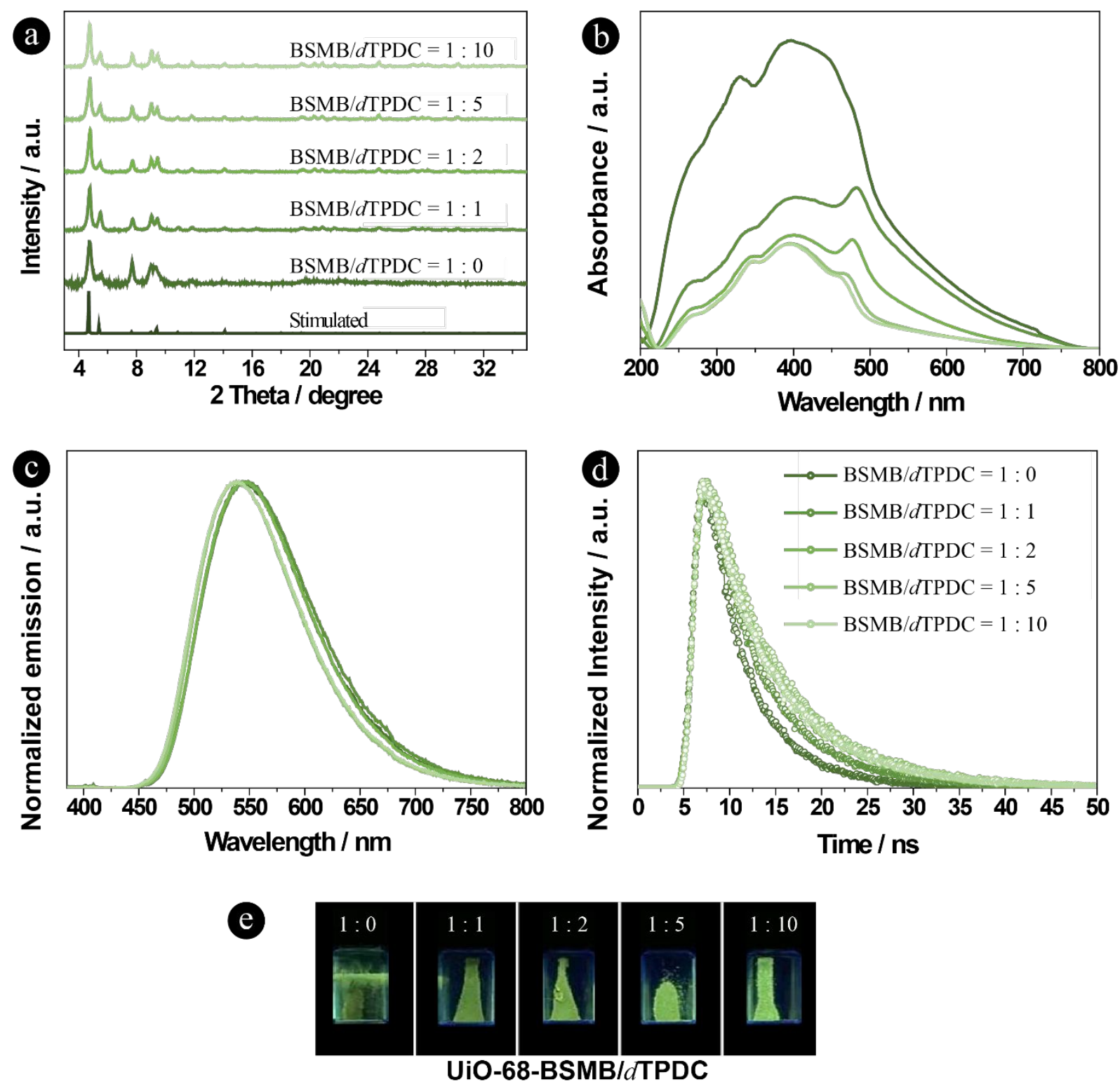

Figure S11. (a) PXRD patterns, (b) solid-state UV-vis absorption spectra, (c) normalized solid-state emission, (d) solid-state transient fluorescence decay profiles and (e) photographs under $365 \mathrm{~nm}$ excitation of mixed linker UiO-68-BSMB with different concentrations of $d$ TPDC. 


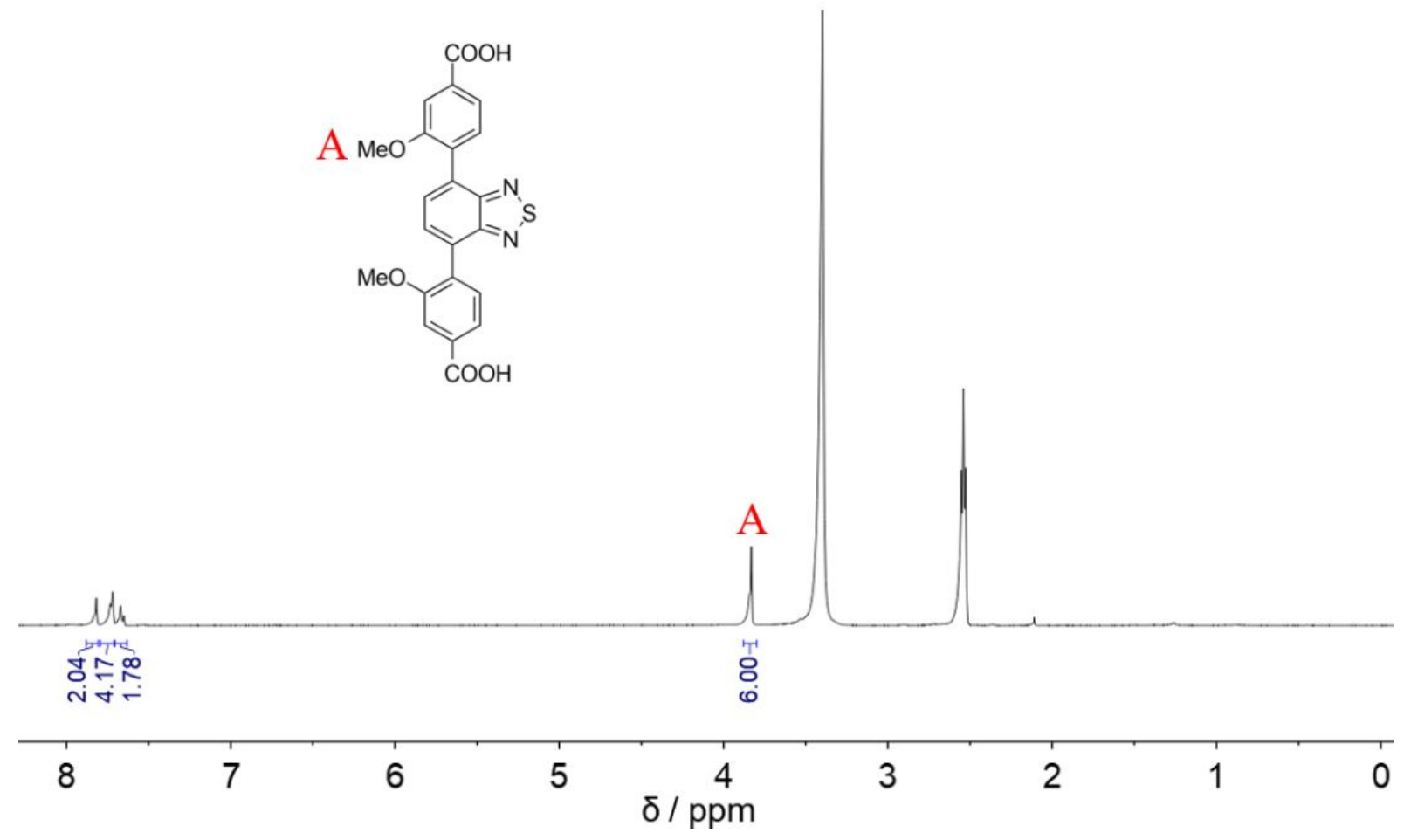

Figure S12. $\quad{ }^{1} \mathrm{H}$ NMR spectrum of acid-digested UiO-68-BTMB. 


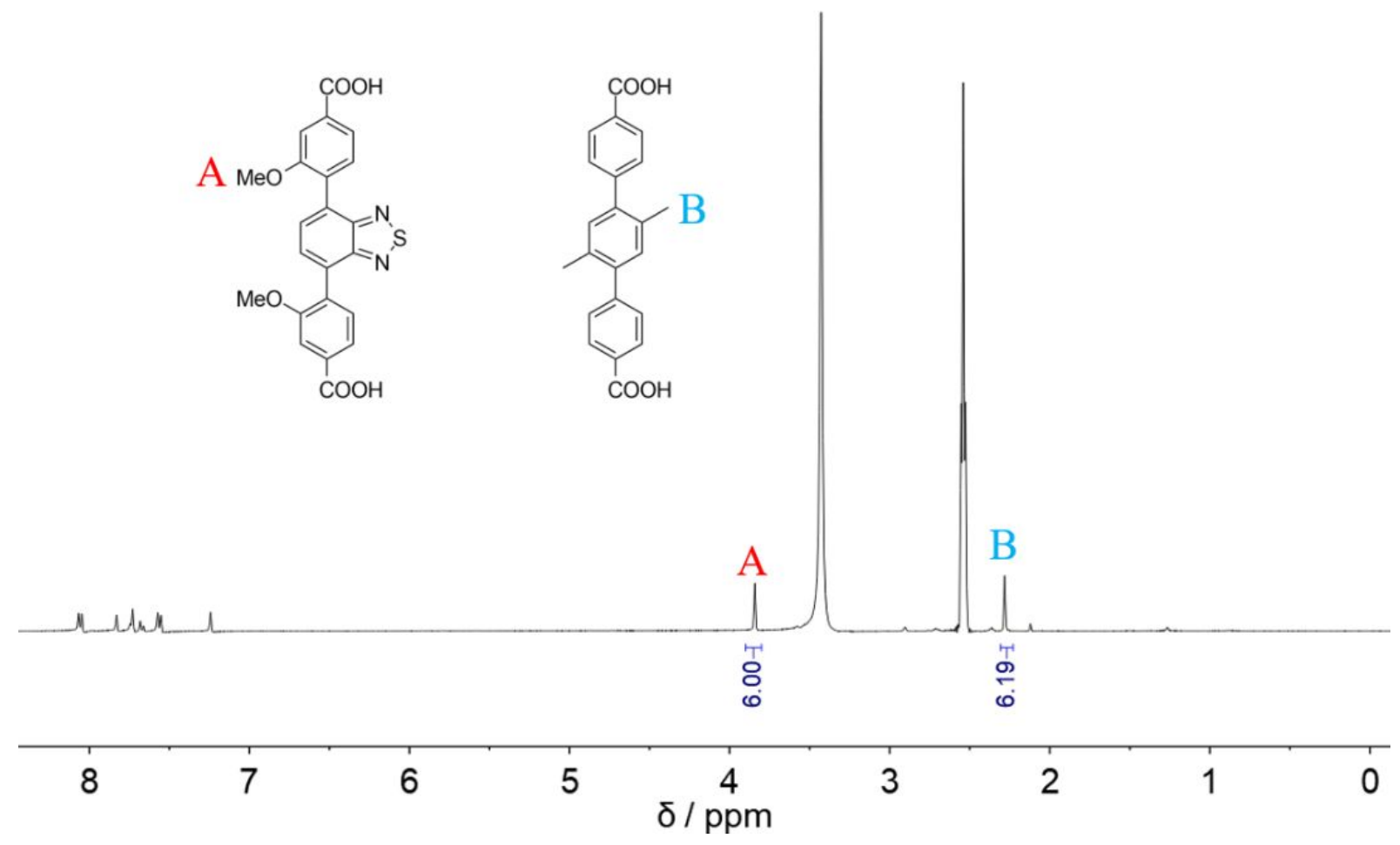

Figure S13. $\quad{ }^{1} \mathrm{H}$ NMR spectrum of acid-digested UiO-68-BTMB/dTPDC. The molar ratio of BTMB : $d \mathrm{TPDC}=6.00: 6.19=1.00: 1.03$ (ratio for synthesis $=1.00: 1.00)$. 


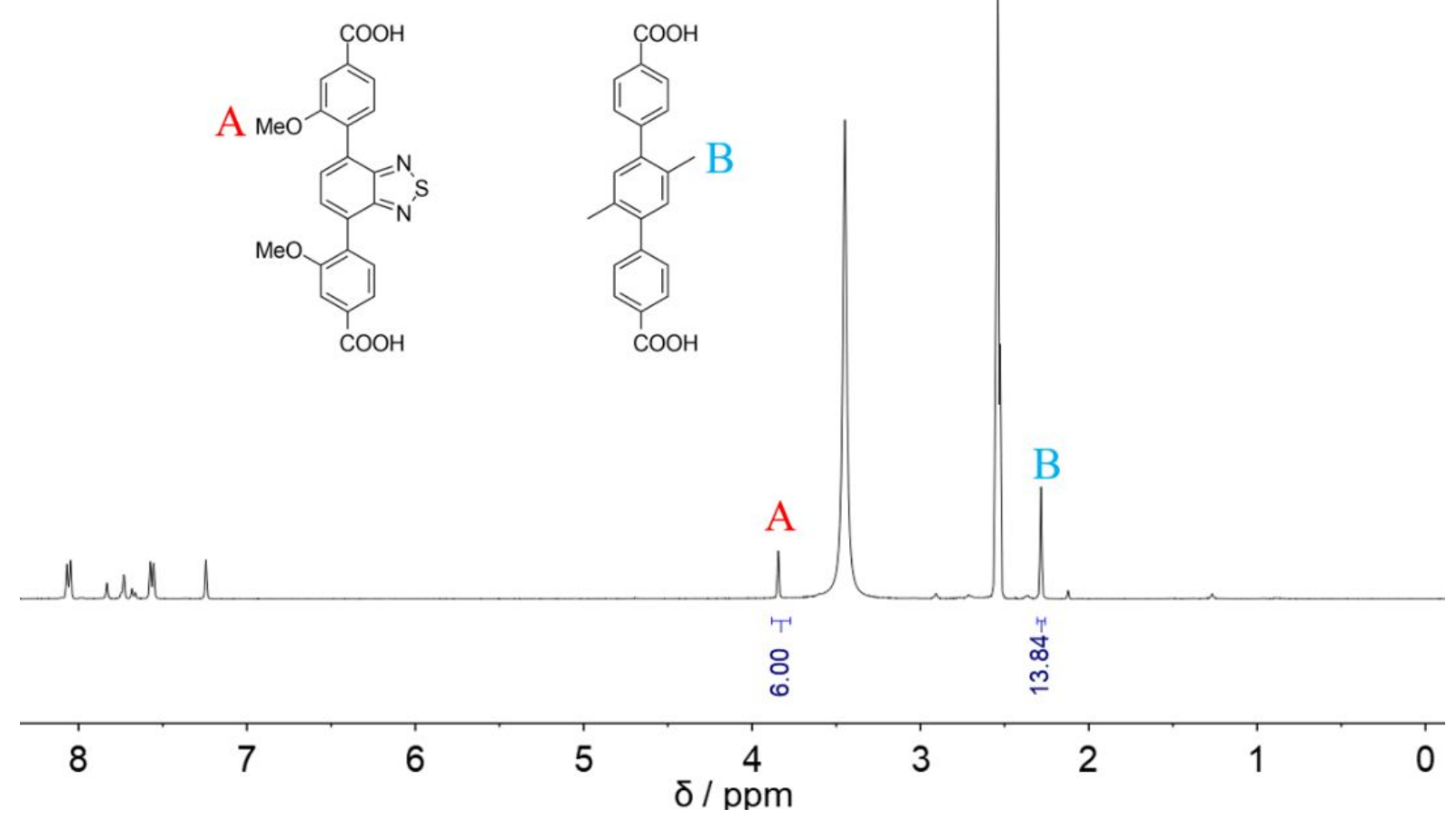

Figure S14. $\quad{ }^{1} \mathrm{H}$ NMR spectrum of acid-digested UiO-68-BTMB/dTPDC. The molar ratio of BTMB : $d \mathrm{TPDC}=6.00: 13.84=1.00: 2.31$ (ratio for synthesis $=1.00: 2.00)$. 


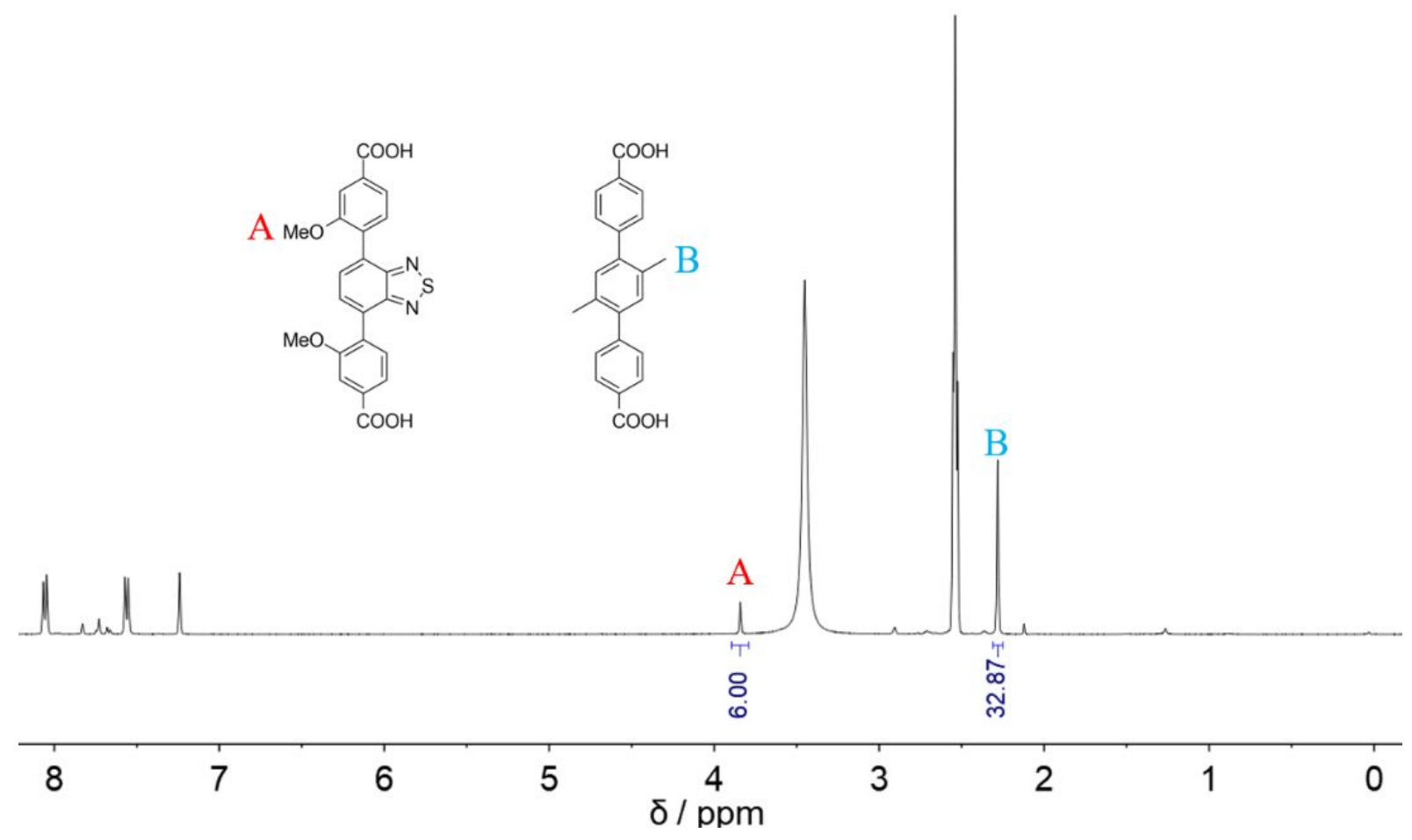

Figure S15. $\quad{ }^{1} \mathrm{H}$ NMR spectrum of acid-digested UiO-68-BTMB/dTPDC. The molar ratio of BTMB : $d \mathrm{TPDC}=6.00: 32.87=1.00: 5.48($ ratio for synthesis $=1.00: 5.00)$. 


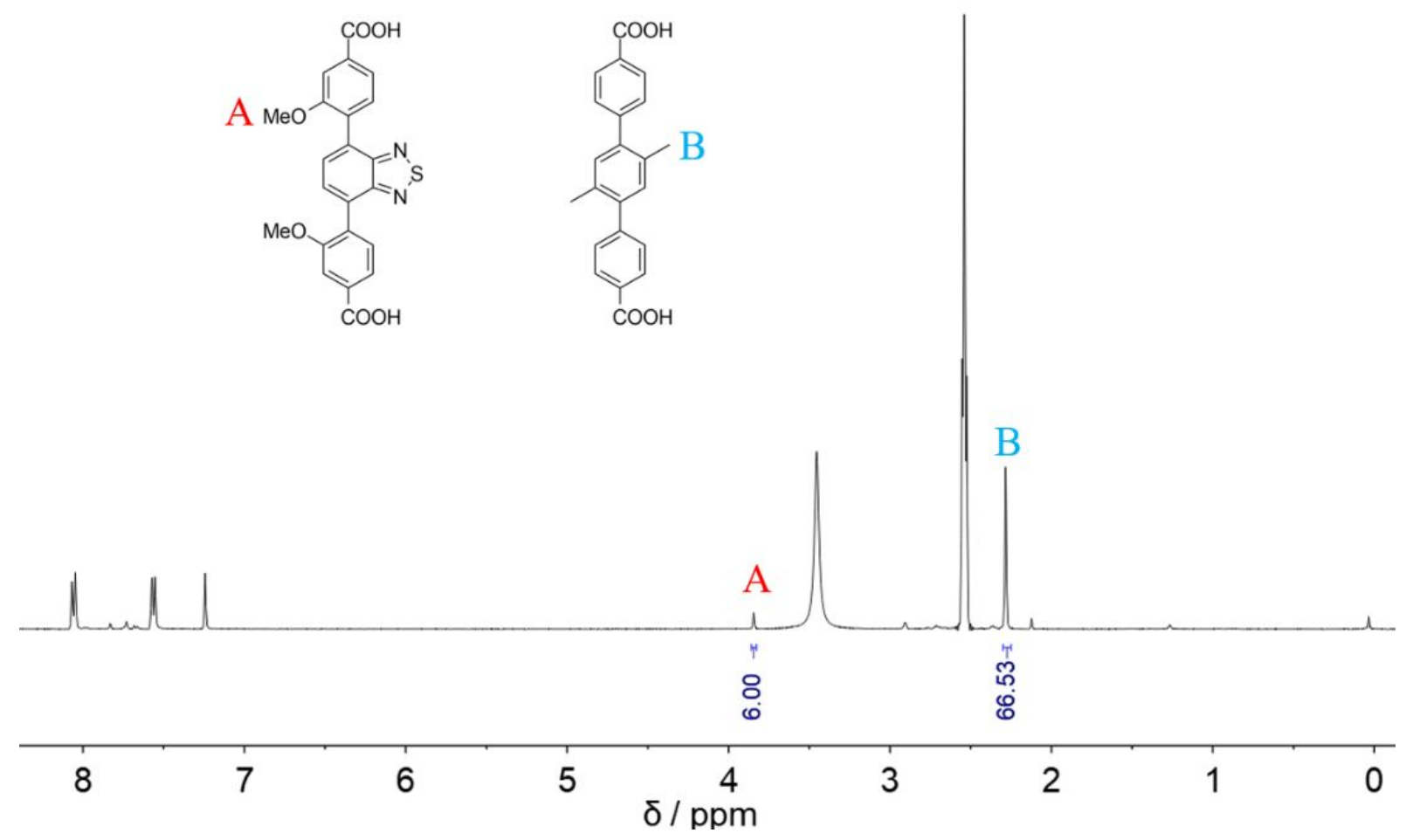

Figure S16. $\quad{ }^{1} \mathrm{H}$ NMR spectrum of acid-digested UiO-68-BTMB/dTPDC. The molar ratio of BTMB : $d \mathrm{TPDC}=6.00: 66.53=1.00: 11.08($ ratio for synthesis $=1.00: 10.00)$. 
Table S3. Crystal data and structure refinement for UiO-68-BTMB.

CCDC No.

Empirical formula

Formula weight

Temperature

Wavelength

Crystal system

Space group

Unit cell dimensions

Volume

$\mathrm{Z}$

Density (calculated)

Absorption coefficient

$\mathrm{F}(000)$

Crystal size

Theta range for data collection

Index ranges

Reflections collected

Independent reflections

Completeness to theta $=48.307^{\circ}$

Refinement method

Data / restraints / parameters

Goodness-of-fit on $\mathrm{F}^{2}$

Final R indices [I $>2 \operatorname{sigma}(\mathrm{I})]$

$\mathrm{R}$ indices (all data)

Extinction coefficient

Largest diff. peak and hole
2082073

C132 H84 N12 O44 S6 Zr6

3281.79

100(2) K

$1.34139 \AA$

Cubic

Fm-3m

$$
\begin{array}{ll}
\mathrm{a}=32.682(2) \AA & \mathrm{a}=90^{\circ} \\
\mathrm{b}=32.682(2) \AA & \mathrm{b}=90^{\circ} \\
\mathrm{c}=32.682(2) \AA & \mathrm{c}=90^{\circ}
\end{array}
$$

34910(7) $\AA^{3}$

4

$0.624 \mathrm{Mg} / \mathrm{m}^{3}$

$1.366 \mathrm{~mm}^{-1}$

6592

$0.120 \times 0.100 \times 0.100 \mathrm{~mm}^{3}$

3.328 to $48.306^{\circ}$.

$-36<=\mathrm{h}<=36,-33<=\mathrm{k}<=36,-36<=1<=27$

37374

$1317[\mathrm{R}($ int $)=0.2459]$

$99.7 \%$

Full-matrix least-squares on $\mathrm{F}^{2}$

1317 / 137 / 108

1.106

$\mathrm{R} 1=0.1309, \mathrm{wR} 2=0.3161$

$\mathrm{R} 1=0.1619, \mathrm{wR} 2=0.3321$

$0.00022(3)$

0.583 and -0.412 e. $\AA^{-3}$ 
Table S4. Crystal data and structure refinement for UiO-68-NTMB.

CCDC No.

Empirical formula

Formula weight

Temperature

Wavelength

Crystal system

Space group

Unit cell dimensions

Volume

Z

Density (calculated)

Absorption coefficient

$\mathrm{F}(000)$

Crystal size

Theta range for data collection

Index ranges

Reflections collected

Independent reflections

Completeness to theta $=47.911^{\circ}$

Refinement method

Data / restraints / parameters

Goodness-of-fit on $\mathrm{F}^{2}$

Final R indices [I $>2 \operatorname{sigma}(\mathrm{I})]$

$\mathrm{R}$ indices (all data)

Extinction coefficient

Largest diff. peak and hole
2082074

C156 H96 N12 O44 S6 Zr6

3582.13

100(2) K

$1.34139 \AA$

Cubic

Fm-3m

$$
\begin{array}{ll}
\mathrm{a}=32.586(4) \AA & \mathrm{a}=90^{\circ} \\
\mathrm{b}=32.586(4) \AA & \mathrm{b}=90^{\circ} \\
\mathrm{c}=32.586(4) \AA & \mathrm{g}=90^{\circ}
\end{array}
$$

34602(13) $\AA^{3}$

4

$0.688 \mathrm{Mg} / \mathrm{m}^{3}$

$1.394 \mathrm{~mm}^{-1}$

7216

$0.150 \times 0.100 \times 0.100 \mathrm{~mm}^{3}$

3.914 to $47.911^{\circ}$.

$-29<=\mathrm{h}<=32,-12<=\mathrm{k}<=36,-19<=\mathrm{l}<=36$

16197

$1283[\mathrm{R}($ int $)=0.2500]$

$99.6 \%$

Full-matrix least-squares on $\mathrm{F}^{2}$

$1283 / 167 / 132$

1.084

$\mathrm{R} 1=0.1155, \mathrm{wR} 2=0.2710$

$\mathrm{R} 1=0.1666, \mathrm{wR} 2=0.2989$

$0.00039(5)$

0.609 and -0.460 e. $\AA^{-3}$ 


\section{References}

1. Ams, M. R.; Trapp, N.; Schwab, A.; Milić, J. V.; Diederich, F., Chalcogen Bonding "2S2N Squares" versus Competing Interactions: Exploring the Recognition Properties of Sulfur. Chem. Eur. J. 2019, 25 (1), 323.

2. Idris, I.; Tannoux, T.; Derridj, F.; Dorcet, V.; Boixel, J.; Guerchais, V.; Soulé, J.-F.; Doucet, H., Effective modulation of the photoluminescence properties of 2,1,3-benzothiadiazoles and 2,1,3-benzoselenadiazoles by Pd-catalyzed $\mathrm{C}-\mathrm{H}$ bond arylations. J. Mater. Chem. C 2018, 6 (7), 1731.

3. (a) Lee, C. T.; Yang, W. T.; Parr, R. G. Development of the Colle-Salvetti Correlation-Energy Formula into a Functional of the Electron Density. Phys. Rev. B 1988, 37, 785. (b) Becke, A. D. A new mixing of Hartree-Fock and local density-functional theories. $J$. Chem. Phys. 1993, 98, 1372. (c) Becke, A. D. Density-Functional Thermochemistry. III. The Role of Exact Exchange. J. Chem. Phys. 1993, 98, 5648. (d) Stephens, P. J.; Devlin, F. J.; Chabalowski, C. F.; Frisch, M. J. Ab Initio Calculation of Vibrational Absorption and Circular Dichroism Spectra Using Density Functional Force Fields. J. Phys. Chem. 1994, 98, 11623.

4. Frisch, M. J. et al. Gaussian 09, rev. D.01; Gaussian Inc.: Wallingford, CT, 2013.

5. Dolomanov, O.V., Bourhis, L.J., Gildea, R.J, Howard, J.A.K. \& Puschmann, H. OLEX2:

A Complete Structure Solution, Refinement and Analysis Program. J. Appl. Cryst. 2009, $42,339$.

6. Sheldrick, G.M. SHELXT-Integrated Space-Group and Crystal-Structure Determination. Acta Cryst. 2015, A71, 3.

7. Sheldrick, G.M. Crystal Structure Refinement with SHELXL. Acta Cryst. 2015, C71, 3. 